\title{
Die Christologiese en Pneumatologiese grondslag van die homiletiek: Perspektiewe vanuit $A$ A van Ruler se denke
}

C J A Vos

\section{ABSTRACT}

The Christological and Pneumatological basis of homiletics

Perspectives from A A van Ruler's reflections

$A$ A van Ruler's thorough thinking about the differences beween the Christological and Pneumatological structures indicates a way for homiletics. In this article the homiletic perspectives which arise from Van Ruler's reflections are exploited.

In sy beroemdgeworde voordrag oor die Structuurverschillen tussen het christologische en het pneumatologische gezichtspunt open A A van Ruler ${ }^{1}$ boeiende perspektiewe wat ook in die homiletiek ontgin kan word. Die homiletiek behoort van die christologiese en pneumatologiese struktuurverskille waarop Van Ruler die aandag gevestig het, kennis te neem. Die rede hiervoor is omdat die verskille noodsaaklik is om reg aan die Christologie en die pneumatologie te laat geskied.

In die preek is die heil van God sentraal. Daarom moet ons eers ' $n$ antwoord op die vraag: wat is heil?, gee. Die mees omvattende omskrywing daarvan is dat dit verlossing, redding is. Redding uit verlorenheid, redding vir die mens en die wêreld. Die mens word nie van sy liggaam verlos nie, ook nie van die wêreld nie, maar die hele mens, die tydelike aardse lewe word bevry. Heil wil sê dat ons sonde vergewe word, dat ons skuld nie aan ons toegereken word nie, dat daar met ons straf weggedoen is. Die vergewing van sonde rus in die versoening van skuld. Ons kan nie die heil op enige wyse verwerf of besit nie. Die heil kom van buite, van Bo. Daarom moet die preek die konsentrasie op Christus volhou. Hy is die Heilsmiddelaar en die Heilsrealiseerder. Die heil moet egter ook pneumatologies geëffektueer word. Die Gees is die Persoon wat die heil bemiddel. Hy verlig die prediker en die hoorder. Die verligting het 'n christologiese gerigtheid. Die Gees wil dat mense in Christus glo.

In die bemiddeling van die heil gebruik die Heilige Gees die skrifgeworde Woord wat verkondig word om die verhaal van God se heilsbemoeienis te vertel. In die gereformeerde tradisie is die Woord ' $n$ heilsmidde ${ }^{2}$. Die preek doen iets. Dit skenk heil. In die preek word nie net aspekte van die heil aan ons geskenk nie, maar die volle heil van God in Christus kom in die preek na ons toe. Daarom moet 
die prediker die volle raad van God verkondig. Hy mag nie met sy liefhebberye besig wees nie. Die preek doen wel iets, maar nie alles nie. Die heil wat deur die preek geskenk word, moet aangeneem word. Daar is 'n verskil tussen ontvang en aanvaar. Die vraag is nie alleen: wat doen die preek met my nie?, maar ook: wat doen ek met die preek? Anders gestel: wat doen ek met die heil wat die Gees aan my skenk? Die Gees rand ons nie aan nie, maar oorreed ons tot die heil3. Hy gee ons die geloof om die heil te aanvaar.

Die wyse waarop die homiletiese perspektiewe in die artikel ontgin word, is deur eers Van Ruler oor ' $n$ bepaalde christologiese en pneumatologiese struktuurverskil aan die woord te stel en om dan die homiletiese implikasies aan te wys. Plek-plek word kritiese opmerkinge oor Van Ruler se teologisering gemaak.

Van Ruler beweer dat daar oor die Christelike heil en gevolglik oor die verhouding tussen God en mens steeds vanuit twee gesigspunte, die christologiese en die pneumatologiese, besin moet word. Die heil is ten volle, sonder res en voorbehoud, in Christus gegee. Elke nuwe mens is egter 'n nuwe realiteit, aan wie die heil ten eerste bemiddel en ten tweede toegeëien en toegepas en in wie dit ten derde uitgewerk moet word. Christus moet gepreek en in Hom moet geglo word. Om dit te kan doen is 'n pneumatologiese beligting nodig. Die geloof, die preek, die liturgie, die sakrament, die geloofsgemeenskap, die tradisie, die amp, die sending; dit alles vra 'n pneumatologiese visie. Die heil wat ons ontvang is 'n goddelike realiteit, maar: in die modus van die Heilige Gees, nie in die modus van Christus nie.

Teen die agtergrond lig Van Ruler die struktuurverskille tussen die christologie en die pneumatologie soos volg toe: die christologie is vanselfsprekend op die agtergrond van die pneumatologie. Sonder Jesus Christus en sy werk is daar geen uitstorting en inwoning van die Heilige Gees nie. Die Messias en die Pneuma is twee gawes en dade van een en dieselfde God. Die Vader, die Seun en die Heilige Gees is die een en waaragtige God.

'n Mens kan die struktuur van die pneumatologie nie klakkeloos aan die christologie ontleen nie. Die rede is dat die realiteit van "God in ons" 'n ander saak as die realiteit van "God in Christus" is. Die wyse waarop ek - deur en in die Gees in myself verlos is en word, altans deel het aan die verlossing, sien daar anders uit, ook struktureel, as die wyse waarop ek in Christus voorwerp van die verlossing is.

$\mathrm{Al}$ is dit alles waar, is daar tog 'n spreiding in die triniteit. Die Seun is nie die Vader nie, en die Gees is nie die Vader of die Seun nie. Die verlossing is anders as die skepping en die heiliging anders as die verlossing. Die uitstorting van die Gees is ' $n$ nuwe en ander daad van God as die vleeswording van die Woord.

In die preek vorm die christologie die agtergrond van die pneumatologie. In dié opsig het die christologie 'n heilsvoorrang. Dit is die grondslag en die bron van die heil en die preek. Sonder Jesus Christus en sy heilswerk is daar geen 
uitstorting en inwoning van die Gees nie. En as die Gees nie uitgestort is en by mense kom inwoon het nie, is alle preke tevergeefs. Die vleeswording en die uitstorting verskil van mekaar, maar albei is noodsaaklik vir die realisering en effektuering van die heil. In die preek gaan dit om die realisering én die effektuering. Vir die preek beteken die pneumatologie dat die neerslag van die heil ervaar word. Die pneumatologie skep die heil soos water uit die christologiese put. Sonder die Gees bly Christus aan die kruis. Die Heilige Gees rol die klippe van die graf weg sodat die lewende Christus kan opstaan en verkondig kan word.

Die eerste struktuurverskil le daarin dat die enhypostasie in die christologie die misterie van die inkarnasie in die kern van die saak in 'n formule saamsnoer, maar in die pneumatologie totaal onbruikbaar is. In die christologie is die leer van die unio personalis sive hypostatica die beslissende moment. Hiermee word uitgedruk dat in die persoon van die Logos die goddelike en die menslike natuur, die Godwees en die menswees, verenig is. Dit beteken ook dat die menslike natuur wat deur die Logos aangeneem is, die natura humana assumta, geen eie hypostasis, geen eie ek, geen eie persoon het nie, maar sy hypostasis in die Logos self vind.

In die pneumatologie durf daar nie in die christologiese kategorieë gedink word nie. As dit toegelaat word, sou die mens in en deur die werk van die Heilige Gees sy hypostasis in God vind! Dit sou die einde van die pneumatologie beteken. In die pneumatologie kom alles daarop aan dat ek - die mens, ook die enkele mens deur die inwoning van die Gees in my, myself is en bly. Die Middelaar en sy werk is die weg waarlangs dit bereik word.

Van die Christen en die kerk, van die mens en die wêreld in die staat van verlostheid is nie alleen van geen anhypostasie nie, maar ook van geen enhypostasie sprake nie. In die Gees is daar wel 'n verhouding, selfs 'n vereniging van God en mens, maar dit is nie enhypostaties van aard nie.

Die inkarnasie bly 'n misterie. Christus het 'n menslike bestaan aangeneem sonder om sy Godheid prys te gee. In sy persoon is sy goddelike en menslike bestaan verenig. En tog was Jesus so onopvallend. Hy was so beskeie en nederig dat mense op Hom neergesien het. Hy het so baie na 'n kneg en so min na 'n koning gelyk dat mense Hom gekruisig het. Dit is egter die wyse waarop God sy Heer-likheid geopenbaar het (Joh 1:14). Hy is Immanuel (Mat 1:23). Dit is hierdie Jesus wat mens geword het, maar terselfdertyd God gebly het wat verkondig moet word. In sy menswording lê die versoening van ons sonde gewaarborg en in sy Godheid ons oorwinning oor die sonde en die dood. In die preek vanuit pneumatologiese perspektief moet rekening gehou word dat die mens homself bly. Die inwoning van die Gees mak nie van die mens 'n godmens nie. Wel God se mens, maar nog volledig mens.

Met hierdie eerste bepaling - christologies wel enhypostasie, pneumatolo- 
gies nie - hang daar onmiddellik 'n tweede saak saam. In die christologie gaan dit om die menslike natuur wat deur die Logos aangeneem is en in die eenheid van sy persoon opgeneem is. Die Logos het in sy vleeswording nie 'n bepaalde mens, 'n persoon wat reeds daar was nie, maar die menslike natuur aangeneem. Die natuur is ex Maria geskep, want die vorming geskied deur iussio en benedictio. In die pneumatologie daarenteen, gaan dit nie om die menslike natuur nie, maar juis om die menslike persoon, om mense waarin die Gees inwoon. Die persoon in wie die Gees inwoon, word nie eers geskep nie. Hy was reeds daar. Selfs al gaan die inwoning van die Gees met wedergeboorte gepaard, word die geboorte veronderstel. Die wedergeboorte is wel in terme van die krag wat daarvoor nodig is, met die creatio te vergelyk, maar nie in terme van dit wat tydens die wedergeboorte gebeur nie. Dit is nie 'n nova creatio nie, maar ' $n$ recreatio.

Met hierdie onderskeiding word nie bedoel om te ontken dat Jesus 'n eie persoon geword het nie. Inteendeel, die Seun van God in die menslike vlees was 'n eie unieke persoon. Ook as die opgestane en verheerlikte Here is Hy meer as 'n funksie, 'n ideogram vir die verhouding tussen God en mens. Hy is steeds Homself.

Die christologiese kategorie is nie adopsie nie, maar assumpsie. Die vlees, die menslike natuur, die menslike bestaan word toegevoeg aan die Goddelike bestaan. Dit kan nie van die mens en die mensheid, van die Christen gesê word nie. Die skepping is ' $n$ eie werklikheid teenoor God, daarom sal 'n mens pneumatologies van adopsie moet bly praat. In die assumpsie word die menslike natuur toegevoeg aan..., in die adopsie word mense in 'n teenoor geplaas met... Die aksent op die persoon en die werk van die Heilige Gees bring mee dat in die besinning oor die heil en die verhouding tussen God en mens ook die mens as individu ernstig opgeneem moet word. Dit gaan daarom dat ek self deel kry aan die heil, en dat dit nie buite my lewe, wete en wil omgaan nie. Die werk van die Heilige Gees wil volledig menslike gestalte kry, in my, in dit wat ek dink en wil en doen. Daar kan onmoontlik met ' $n$ kerklike gestalte volstaan word. In die suiwer kerklikheid skuil nog 'n halwe dosetisme. Van Ruler stel die vraag of die sekerheid nie net sekerheid aangaande die heil, certitudo salutis is nie, maar ook sekerheid aangaande my deelname aan die heil is en in dié sin certitudo fidei is. Die heil is dan nie alleen objek van my geloof nie, maar ek is by wyse van spreke ook objek van die heil.

Dit gaan nie soseer om die Verlosser nie. Selfs nie om die verlossing nie. Maar veelmeer om die verloste. En dan nie alleen daarom dat hy verlos is nie, maar veral om die dat en die wat van die verlossing. Die wese van die geloof bestaan dan in selfbe-aming, aanvaarding van die wêreld, geesdrif vir die bestaan.

In die christologiese kategorie van die enhypostasie gaan dit om die vereniging van die goddelike en die menslike bestaan in die persoon van Christus. In die pneumatologie lê die klem op die feit dat die Gees in mense woon wat reeds bestaan. Die preek is die wyse waarop die Gees mense deur die saad van die 
Woord wederbaar (1 Petrus 1:23-24) en van sy inwoning bewus maak.

In die christologie staan die term assumptio sentraal. Die aanname van die menslike bestaan is deur die sonde genoodsaak. God het sy Seun in dieselfde gestalte as die sondige mens gestuur as 'n offer vir die sonde (Rom 8:3). Op dié wyse het $\mathrm{Hy}$ die weg vir ons verlossing gebaan. Hierdie christologiese swaartepunt is die snypunt van ons verlossing en moet daarom in die prediking onverswak verkondig word. In pneumatologiese terme moet daar van adopsie gepraat word. Die inwoning van die Gees bring mee dat die mens voor God gehandhaaf word. Hy word wel deur die Gees se toedoen as God se kind aangeneem, maar hy staan nog as mens teenoor God. Die preek het as doel om die adopsie deur die Gees tot stand te laat kom. As dit gebeur, bly die geadopteerde mens, mens teenoor God.

Die pneumatologie neem die mens as individu ernstig op. Die mens kry self deel aan die heil en dit vind nie buite sy lewe, wil en wete om plaas nie. Verder kry die werk van die Gees volledige gestalte in dit wat die mens se, dink en doen. Die gemeente is nie net 'n korporatiewe gemeenskap nie, maar ook 'n gemeenskap wat uit enkelinge bestaan. Daarom moet die individu in die preek ernstig opgeneem word. Die enkeling moet ervaar dat hy in die preek aangespreek word. Die heil wat deur die preek geskenk word, gaan nie by die mens se lewe, wete en wil verby nie. In die preek moet die oproep juis weerklink dat die heil in die mens se denke, wil en dade gestalte moet kry. Op dié wyse word die heil in die wêreld sigbaar.

Die derde struktuurverskil fokus op die christologie waarin die gedagte van plaasvervanging oor die hele linie van deurslaggewende betekenis is. Die Messias doen en is alles, wat Hy doen en is, vind in ons plek en in ons belang plaas. Die middelaarskap is plaasvervangend. In die pneumatologie is die gedagte van plaasvervanging onbruikbaar. Dit is steeds God die Heilige Gees, wat nie alleen in en aan ons nie, maar eintlik steeds ook met ons - in die sin van "saam met" ons handel. Hy getuig tot ons gees, maar Hy getuig ook met ons gees. Hy kom ons in ons swakheid te hulp en sug in ons met onuitspreeklike sugtinge, maar op so 'n wyse, dat Hy op dieselfde oomblik in ons sugte losmaak. Wat in die christologie plaasvervanging heet, heet in die pneumatologie resiprositeit. Teonome resiprositeit: dit is die Gees wat alles doen en gee, wat byvoorbeeld ons wil vrymaak sodat ons 'n vrye wil kry. Maar resiprositeit: die kenmerkende van die werk van die Gees is dat $\mathbf{H y}$ ons aan die werk sit. Die uniekheid van hierdie resiprositeit lê daarin dat die mens ook tot die Middelaar, wat in sy plek staan, in 'n verhouding van resiprositeit te staan kom. Die mens laat hom vervang. Hy laat die Middelaar in sy plek staan. Hy sien die noodsaak daarvan in.

Dit is nie alleen God wat die mens regverdig nie (iustificatio Dei activa), maar die mens regverdig God ook (iustificatio Dei passiva). Die mens sien in dat dit waar is wat God sê: dat die mens sondaar is en dat God regverdig is, dat in Christus 
verlossing is en dat die mens so kind van God is. Deur die Gees kom daar evidensie in die verhouding van God en mens en in die heil. Die mens moet die dinge egter self insien en ook wil, anders kan hy nie behou word nie.

Chistologies het die goddelike beslissing eenmalig en afdoende geval, maar pneumatologies moet daar ook nog 'n beslissing in die hart van die mens val. Wat in die christologie plaasvervanging en in die pneumatologie resiprositeit heet, is vir die prediking onopgeefbaar. Die preek rus op die plaasvervanging van Christus. Sonder die plaasvervangende Middelaarskap bly die mens in die mag van die sonde. Hy bly skuldig voor God. Al loon wat hom toekom, is die dood (Rom 6:23). Daar is dan niemand wat in sy plek vir hom versoening kan bewerk nie. Dit is die plaasvervangende Middelaarskap van Christus wat die goeie nuus deur die preek heen loslaat. Die aksent op die pneumatologiese resiprositeit laat die mens deur die preek ontdek dat die Gees alles gee en doen. Die kenmerkende van die Gees is egter dat Hy die mens aan die werk sit. Daarom moet die imperatief, die appèl, die etiek in die preek voluit funksioneer. Natuurlik is dit gegrond op die heilsindikatief (die plaasvervanging). Die resiprositeit laat die mens ook sy plek voor die Middelaar ken. In die preek laat die Gees die mens ontdek dat dit waar is wat God sê: die mens is sondaar en God is regverdig. "Ek, ellendige mens! Wie sal my van hierdie doodsbestaan verlos? Aan God die dank! Hy doen dit deur Jesus Christus ons Here" (Rom 7:24-25). Die Gees laat die sondaar deur die preek insien: Christus alleen. Daarom kom staan die mens ook in 'n verhouding van resiprositeit tot die Middelaar. Dit beteken dat die mens op aandrang van die Gees toelaat dat Christus, die Middelaar sy plek inneem. Daarin lê sy behoud. In die preek word nie alleen die voldonge goddelike beslissing uitgeroep nie - die beslissing wat in Christus voltrek is, maar daar word ook tot nuwe goddelike beslissinge opgeroep beslissinge wat in ons voltrek moet word.

Die vierde struktuurverskil hang ten nouste met die derde saam. Dit handel oor die groot vraagstuk van die versoening en die offer. Dit is sonder meer duidelik dat 'n mens nie oor die heil en die verhouding van God en mens kan praat sonder om op die sentrale plek van die offer te wys nie. Daarvoor is daar 'n Middelaar wat in ons plek die versoeningsoffer gebring het.

In die christologie is die offer sentraal, maar of daar van die offer in die pneumatologie sprake is, is 'n ander vraag. 'n Wydverbreide siening wat oor die offer gehuldig word, word soos volg aangebied: daar is maar een offer, dit is die offer van God die Seun in die menslike vlees, dit is die offer van die versoening en in die werk van die Gees word niks minder nie as die een offer ten volle aan ons voltrek - maar dan uiteraard as offer van die heiliging en die verheerliking. Die offer is alleen offer van die versoening as dit plaasvervangend gebring word en deurdat dit in toeëiening en toepassing aan ons voltrek word, is dit die offer van die heiliging en die verheerliking. Hierom gaan dit trouens: die versoening is slegs die 
middel, die heiliging en die verheerliking is die doel.

Tog is die saak op dié wyse miskien te eenvoudig voorgestel. Heiliging en verheerliking is in ieder geval momente in die verlossing. Kan 'n mens egter op geen wyse van versoening praat nie? ' $n$ Mens kan nie van versoening in die sin van expiatio en placatio praat nie. Dit is realiteite waarmee alleen God die Seun in die vlees raad weet. Expiatio en placatio kom slegs in die situasie van plaasvervanging voor. Maar word God en mens in die heiliging en verheerliking nie met mekaar versoen nie en is in dié sin die eksistensiële, liturgiese en sakramentele offer nie ook 'n offer van versoening, ' $n$ offer van die reconciliatio te noem nie? Vind daar in die nagmaal, in die liturgie en in die Christelike lewe geen reconciliatio plaas nie? Moet ons nie in 'n pneumatologiese deurgronding van die plek en die wese van die nagmaal die gedagte van die offer, met name ook as offer van versoening in die sin van reconciliatio, opneem nie?

Die struktuurverskil tussen die christologiese en die pneumatologiese gesigspunt ten opsigte van die offer lê dus nie in die onderskeid van versoening en dankbaarheid nie, maar in expiatio en placatio enersyds en reconcilio, sanctificatio en glorificatio andersyds, waarby dankbaarheid slegs 'n moment in die heiliging is.

Die onvervangbare plek en funksie van die plaasvervanging in die prediking is reeds behandel. Hier gaan dit om 'n saak wat nou daarby aansluit: die versoening en die offer. Versoening in die sin van expiatio en placatio is uitsluitlik christologiese begrippe. Net Christus se soenoffer kan God en mens, mens en mens versoen. Dit moet in die preek tydig en ontydig verkondig word. In die pneumatologie word die begrip versoening op die heiliging en die verheerliking toegespits. Die versoening tussen God en mens moet in die heiliging en die verheerliking gevier word. In die lig hiervan moet daar erns gemaak word met die reconciliatio in die preek, die liturgie, die nagmaal en die Christelike lewe.

In die vyfde struktuurverskil fokus Van Ruler op die ef hapax moment van die offer. Jesus Christus het die offer van versoening op Golgota eenmaal eens en vir altyd gebring. Daarom is dit ook 'n algenoegsame offer. Die sekerheid van die heil rus ten volle daarin. In die pneumatologie moet daar net soos in die christologie van 'n ef' hapax gepraat word. Pneumatologies word op die ef' hapax van die uitstorting van die Heilige Gees as eenmalige heilsfeit in die kring van ander heilsfeite gedui. Die uitstorting het ook in Israel, in Palestina plaasgevind, eweseer as die vleeswording van die Woord, die offer van versoening, die opstanding uit die dood en die hemelvaart.

Die ef' hapax van die uitstorting van die Heilige Gees het egter 'n heel ander struktuur en betekenis as die ef' hapax van byvoorbeeld die offer van die versoening. Aan die katabasis van die Gees beantwoord geen anabasis soos by Jesus Christus nie. Hy bly sedert sy uitstorting op aarde. Die ryk van God is nie soos 'n meeu, wat - in die inkarnasie - die water van die tydelike werklikheid raak, om dan 
weer op te vlieg en daar buite te staan tot die jongste dag nie. Die ryk van God is hier en nou teenwoordig. Dit het nie alleen die gestalte van die Messias nie, maar ook van die Pneuma. Die gestalte van die Pneuma is meer die doel as die van die Messias. Dit gaan om ons en om ons wêreld en daarom dat ons onsself as beeld van God en hierdie wêreld as sy ryk beleef. Dit alles bewerk die Gees vir ons. Hiervoor woon $\mathrm{Hy}$ by ons. Die ef' hapax van die pneumatologie dra ook'n sekerheid. Dit is die sekerheid in die gestalte van geesdrif vir die bestaan. Die Gees gee ons moed vir die lewe en die wêreld. Die ef' hapax aard van Christus se offer benadruk die algenoegsaamheid en die voltooidheid daarvan. Hierin rus die sekerheid van die heil. Vir die prediking is die sekerheid wat verkondig word, van groot belang. Die ef hapax van die Gees se uitstorting gee aan die kerk en elke gelowige die sekerheid dat God nie die werk van sy hande prysgee nie. In hierdie wêreld is ons God se beelddraers en is sy ryk werksaam. Hiervoor staan die Gees borg. Vir die prediking hou dit onder andere in dat preke 'n koninkrykperspektief moet hẻ. God vestig sy koninkryk in hierdie wêreld. Hier moet ons as burgers van sy koninkryk leef.

Die sesde struktuurverskil handel oor die inwoning van die Gees. Om die kontinuiteitsaspek van die ef' hapax van die uitstorting uit te druk, gryp ons onwillekeurig na die begrip inwoning. Dit is wat van God die Gees gesê moet word: $\mathrm{Hy}$ woon in en by ons in. In die worsteling rondom die Nestoriaanse en aanverwante gedagtegange het dit wel duidelik geword dat die spreke van alleen maar'n inwoning van die goddelike of God in die mens Jesus christologies beslis onvoldoende is. Die unio personalis wys op 'n diepere, inniger vereniging. Hierdie inniger vereniging is volstrek nodig sodat God die Seun in die menslike vlees die werk van versoening en verlossing kon voltrek. In die pneumatologie mag 'n mens vir geen prys een tree verder gaan nie. God die Gees, die drie-enige God op die wyse van die Gees, woon in en by ons in. Die inwoning het ' $n$ individuele en ' $n$ gemeentelike kant. Die Gees besit die individu, maar ook die gemeente. Indien 'n dieper en inniger vereniging tussen God en mens verlang word, kom 'n mens onvermydelik tot die vergoddeliking van die skepsel. Dit sou die ergste wees wat kon gebeur. Die skepsel moet skepsel bly. Sowel die Godheid van God as die mensheid van die mens word gehandhaaf indien daar aan die formule vasgehou word dat God in en by die mens inwoon. 'n Belangrike element in die gedagte van die inwoning is dat dit onwillekeurig die suggestie van die tydelike wek. Soos alle inwoning gaan dit met stryd gepaard. Dit is die stryd van die Gees en die vlees. Indien die stryd die essensie van die inwoning is, beteken dit dat daar ook aan die inwoning 'n einde sal kom. En inderdaad: in die eschaton sal ons die verligting van die Gees nie meer nodig hê nie.

Die christologiese gedagte van die unio personalis stel die Seun van God in staat om die versoening en verlossing te kon voltooi. In die prediking is die christologiese moment die grondslag van die proklamering van die versoening. 
Pneumatologies dui die inwoning van die Gees daarop dat God by die gemeente en die mens inwoon. Die inwoning hef nie die skepselmatigheid op nie, maar hou daarmee rekening. Dat dit inderdaad die geval is, moet in die prediking aan die lig kom. Die Gees bly Gees en die mens bly mens. Daarom word die mens ook in sy menswees aangespreek.

Die inwoning van die Gees staan binne die raam van tydelikheid en eindigheid. Die prediking moet steeds met die vlugtige momente van die menslike bestaan rekening hou.

Uit die sesde struktuurverskil vloei die sewende. Die inwoning van die Gees ontketen 'n stryd. 'n Stryd tussen die inwonende God wat die Gees is en die mens wat in homself vlees is. Die stryd strek oor die hele lewenslinie van die mens. 'n Beslissing val alleen as die Gees die mens aanraak. Die aanraking van die mens deur die Gees word gerealiseer in die aanneming van die Gees deur die mens. Die kategorie aanraking dui op verligting, oortuiging, bevryding. Dit omvat die hele mens: sy verstand, sy wil, sy hart, sy self. Daarom kan die werk van die Gees nie anders omskryf word as deur die kategorie verandering nie. Die wedergeboorte is 'n verandering van die bestaan van die mens.

Die inwonende Gees bring die wedergeboorte tot stand. Hy laat die mens van bo gebore word (Joh 3). Die nuwe mens is nie 'n passiewe mens nie, maar aktief in die sin dat hy deur die Gees tot stryd teen die ou mens (sarks) aangespoor word. Die preek is 'n wyse waarop die Gees die mens strydvaardig maak. Deur die preek maak Hy die mens in sy gevoel, wil, denke gewillig en gretig vir die stryd. Hy gee sy Woord as swaard om die stryd te voer en die oorwinning te behaal. Omdat Hy by die mens inwoon, is die oorwinning gewaarborg. In die preek moet die stryd en oorwinningsperspektiewe helder voor oë gehou word.

In die agste struktuurverskil gaan dit daarom dat die Gees die mens aanraak, maar ook iets uitwerk. Die genade word gratia infusa in die mens. Hy ontvang ook ander gratiae, onder andere charismata.

Die Gees wat by die mens kom inwoon, is ook werksaam in die mens. Dit kom veral deur die charismata aan die lig. Oor die charismata moet daar enkele opmerkinge gemaak word. Dit is gawes van God drie-enig. Daar is 'n verskeidenheid gawes. Verder is dit tot voordeel van alle gemeentelede'. Die preek moet die gawes nie blus of vervang nie, maar aanwakker. Op dié wyse dien die preek die opbou van die gemeente.

Van Ruler fokus vervolgens op die volgende vrae: Hoe is die verhouding van die nuwe wat die mens ontvang en die oue wat hy gehad het en was? In die taaleie van Rome: wat is die verhouding van genade en natuur? In 'n ander idioom: wat is die verhouding van heil en eksistensie? Die natuur en die eksistensie is nie uit Christus en deur die Gees nie. Dit beteken egter nie dat dit nie van God kom nie. Dit kom uit die skepping en die geboorte. Die sonde het ook diep daarop ingewerk. 
Ten einde die verhouding van heil en eksistensie te peil, oorweeg Van Ruler die kategorie van vermenging om die Gees se werk te beskryf. In die christologie is die kategorie afgewys. Dit lei tot monoteïsme. Dit sou 'n vermenging van die wese van God en die wese van die mens wees. Dit volg onmiddellik uit die unio personalis. Maar in die pneumatologie sien sake daar anders uit. Daar staan alles teen die agtergrond van die inhabitatio. As daar sprake van vermenging is, gaan dit om die vermenging van die goddelike heil in Christus met die geskape en gevalle eksistensie van die mens. Daar vind egte applicatio plaas. Dit is nie net 'n applicatio in nos nie, maar ook 'n applicatio in nobis. Christus kry gestalte in ons. Dit beteken ook altyd: Hy kry ook gestalte uit ons. In elke mens, in elke volk, in elke kultuur, in elke eeu ook weer anders.

In die pneumatologiese gedagte van die vermenging gaan dit om 'n sintese van die besondere en die algemene, in prinsipe om 'n sintese van die verlossing en die skepping en word aan die ex Maria uit die christologie 'n enorme uitbreiding, verbreding en verdieping gegee.

Van Ruler beskryf die verhouding tussen die heil en die eksistensie pneumatologies in terme van vermenging. Dit is egter 'n te groot risiko. In vermenging sit daar die gedagte van twee dele wat versmelt. In die proses gee elkeen ter wille van die nuwe vorm sy eienskappe prys. In die verhouding tussen heil en eksistensie val die verhouding anders uit. Die heil heilig, omvorm en herskep die menslike eksistensie wel, maar dit lei nie tot vermenging nie. Deur die heil kom daar nuwe relasies tot stand: Christus kry gestalte in en deur ons as nuwe mense. Die preek is die wyse waarop die Gees deur middel van die heil die menslike eksistensie aanraak en herskep. In en deur nuwe mense kry Christus gestalte.

In 'n slotbeweging gee Van Ruler aandag aan nog 'n paar struktuurverskille. In christologiese verband moet 'n mens beslis in perfektionistiese toonaard praat. Jesus is die algenoegsame Saligmaker. Hy is die nuwe Mens, sonder sonde. Deur imputatio en unio mystica is ons die nuwe mens. Wie in Hom bly, sondig nie. Pneumatologies is die perfeksionisme egter 'n lewensgevaarlike kettery. Die Gees kan wel heelwat vermag. Die Christen en die kerk is goddelike realiteite. Daar word reëel met die sonde en die kwaad gestoei. Maar die inwoning van die Gees word voltrek in die bittere en dodelike stryd met die vlees. In die versoening word daar nie weggedoen met die kwaad nie, maar dit word bedek.

Die vermyding van perfeksionisme in pneumatologiese kategorieë moet in die prediking voluit gehandhaaf word. In die preek word die mens tot 'n onophoudelike stryd met die ou mens opgeroep. Daar word 'n appel op hom gedoen om sy posisie in Christus in te neem (Rom 8 ).

'n Verdere struktuurverskil. Christus staan in ons plek. Hy kry bowendien in ons gestalte, maar ons moet in die werk van die Gees ook die omgekeerde lyn trek. Daar is nie alleen sprake van ' $n$ "Hy in ons en in ons plek" nie, maar ook van 
"ons met Hom" en selfs van 'n "ons tot Hom". Dit gebeur deur die Gees met ons: daar vind insitio en insertio plaas. Dit mond uit in 'n unio mystica cum Christo. In die unio mystica gaan dit om die gemeenskap met en die deelgenootskap aan die vrug en verdienste van die werk van Christus, maar ook om die gemeenskap met en die deelgenootskap aan die werk, die kruisdood en die opstanding van Christus self.

Die plaasvervanging is ' $n$ fondament vir die prediking. Hy staan in ons plek en kry ook in ons gestalte. Die pneumatologie skep 'n verdere beweging vir die preek. Christus is nie net in ons plek en in ons nie, maar ons is ook deur die Gees met Hom en in Hom. Hierdie innige band met Christus moet deur die preek versterk word.

Van Ruler vra of ons by die gemeenskap met en die deelgenootskap aan die verdienste van die werk van Christus en die gemeenskap met en die deelgenootskap aan die werk, die kruisdood en die opstanding van Christus kan bly staan. Is daar nie deur die Gees 'n méér as Christus nie, in die sin dat die unio mystica ook 'n mystica met die drie-enige God self is nie? Lei die Gees ons nie deur die gebed en die meditasie heen tot die kontemplasie en die spekulasie nie? Miskien aanskou ons dan nie God se wese nie, maar dan tog in ieder geval sy ewige raad, die ewige uitverkiesing. Deur die Gees verstaan ek myself as van ewigheid verkore en tot in ewigheid behoue. Die predestinasie en die volharding is van hieruit pneumatologiese gesigspunte.

In die prediking is dit moontlik om mér van die Gees as van Christus te praat. Hierdeur word Christus nie oneer aangedoen nie. Hiermee word bedoel dat die Gees die mens nie net met Christus verenig nie, maar met God drie-enig. In die preek mag die visie op God drie-enig nooit uit die oog verloor word nie.

Van Ruler oorweeg 'n nuwe pneumatologiese kategorie, dié van die theopoiesis. Deur die Gees weet, wil, doen ek alle dinge met God mee. Daar ontstaan 'n teonome en inhoudelike identiteit tussen God se oordele en my oordele. Christologies kan die heil soos volg geformuler word: God het mens geword. Pneumatologies geformuleer: die mens is besig, om so te sê "God" te word. Die laaste formule moet slegs as 'n pneumatologiese formule, dus vanuit die inwoning, en nie as 'n christologiese formule, byvoorbeeld nie vanuit die unio hypostatica nie, verstaan word. Die theopoiesis vind nie eers in die eschaton plaas nie, maar reeds in die hede. Dit hou vir geen oomblik die element van 'n ontiese verheffing van die skepselmatigheid in nie.

Dit is duidelik dat Van Ruler nie onder theopoiesis ' $n$ vergoddeliking van die mens voorstaan nie. Al woon die Gees by die mens in, bly hy nog mens. Die kwaad bly steeds op sy spoor. Die sonde is ten diepste 'n incurvatus in se. Die Gees herstel die mens in sy eer en heerlikheid voor God. Hy doen dit deur die mens al meer na die beeld van Christus te verander ( 11 Kor 3 ). Hier word hoegenaamd nie in perfeksionistiese kategorieë gedink nie, maar in terme van heiliging en 
verheerliking waartoe God die mens roep en waartoe die Gees hom in staat stel.

Dit bring ons, aldus Van Ruler, by 'n volgende struktuur-verskil. Die kategorie van die vermenging open die venster wat 'n uitsig op die veld van die skepping bied. Ons sien nie net die heil nie, maar ook alles wat in en deur die heil gered word. Dit gaan om alles wat is en wat geskied in skepping en verlossing volgens God se oorspronklike en uiteindelike bedoelinge. Die Gees open die venster na die toekoms toe. Hy neem ons saam na die toekoms toe. Die Gees verkondig aan ons die toekoms wat Hy van die Vader hoor (Joh 16:13). Om dié rede word Hy onderpand, seël, parakleet, bebaiosis, Gees van die erfenis en van die belofte genoem. In al die opsigte is die Gees nie net op Christus en die salus in Hom gerig nie. Hy is veeleer meer op die ewige ryk en die heerlikheid daarvan gerig. Christus self, sy werk en sy ryk is ook daarop gerig. Die struktuurverskil tussen die pneumatologie en die christologie bring mee dat die pneumatologie nog meer vanuit die eskatologie as vanuit die christologie verstaan moet word. Die Gees het nog meer relasie tot die skepping as tot Christus. Die rede hiervoor is omdat Christus veral relasie tot die skuld het.

'n Mens kan nie die indruk ontkom dat Van Ruler hier 'n bietjie eensydig in sy denke is nie. Christus se relasie tot die skuld is die skuld van die skepsel en die skepping. Die Gees se relasie tot die skepping staan nie los van dié van Christus nie. Skuld is nie abstrak nie, maar konkreet, dié van die skepsel en die skepping.

Die uitsig wat die Gees op die skepping en die toekoms bied, laat die prediking asemhaal. Die heil in Christus is ook heil vir die wêreld. Daar is nie net sprake van individuele heil nie, maar ook van kosmiese heil. Die preek moet mense leer om nie vir hierdie wêreld te vlug nie, maar om lief te word vir God se wêreld. Dit moet na vore kom in die mens se behandeling van hierdie wêreld. Die preek is ook nie net met die hede besig nie, maar ook met die toekoms. Die wêreld gaan eenmaal heel word: 'n nuwe hemel en aarde gaan tot stand kom. Die toekoms gee hoop in die hede.

Die christologiese en pneumatologiese struktuurverskille kan met behulp van die skema - middel en doel - en ook met die skema - werk en rus - uitgedruk word. Die werk van die Middelaar is in wese alleen maar middel, die werk van die Gees is ten diepste alleen maar doel. In Christus woon al die volheid van die Godheid liggaamlik. Hy is ons geregtigheid. Hy is die wysheid van God, maar dit gaan daarom dat ons 'n woonplek van God in die Gees word, 'n aangename offer aan God bring, sodat die wysheid van God wat Hy in die skepping neergelê het, weer opstraal. Dan pas, deur die werk van die Gees, in ons, kom God tot rus, dan is Hy waar Hy wil wees; in die Middelaar is Hy alleen maar werksaam.

Natuurlik is die werk van die Gees 'n voorlopige doel en die voorlopige rus. Die Gees maak Homself en sy werk oorbodig. Op die duur is ons Gods heerlikheid. Dit is dan die laaste struktuurverskil: christologies lyk dit asof die heil 
in sy besondere gestalte 'n ewige konsistensie het. Pneumatologies blyk dit dat dit intussen om onsself bly gaan. Die struktuur van die inhabitasie van die Gees dui aan dat die inkarnasie van die Seun nog eens een keer ongedaan gemaak sal word. Trouens, 'n mens moet jouself afvra of die inkarnasie nie reeds ongedaan gemaak kan word in die werk van die Gees nie.

Die Gees omskep die mens as sy woonplek tot sy rusplek. Die woonplek word 'n altaar waar geurige offers wat God welbehaaglik is, opstyg. Die preek moet die mens bewus bly maak dat hy die Gees se woonplek is; dat hy God deur sy liggaam moet verheerlik. Hierom gaan dit ten diepste in die preek: dat die mens God moet verheerlik.

Die windvars manier waarop Van Ruler oor die dogmatiek nagedink het, skuif vensters vir die homiletiek oop. In die artikel is die wind toegelaat om die homiletiese huis 'n bietjie skoon te waai.

\section{NOTAS:}

1 A A van Ruler, Structuurverschillen tussen het christologische en het pneumatologische gezichtspunt. Theologisch Werk. Deel I, Nijkerk 1969, 175190. Vergelyk ook Van Ruler, Hoofdlijnen van een pneumatologie. Theologisch Werk. Deel VI, Nijkerk 1973, 9-40.

2 H Berkhof, Christelijk geloof, Nijkerk 1973, 374; J A Heyns, Dogmatiek, Pretoria 1978, 329; W D Jonker, Die Gees van Christus, Pretoria 1981, 54.

3 Van Ruler, Theologisch Werk. Deel VI, Nijkerk 1973, 34; A A van Ruler, De positie van de mens in het heilsproces. Breuklijnen in kerk en theologie. Hoofdmomenten van het getuienis, Kampen 1974, 82.

4 C J A Vos, God die Heilige Gees, Pretoria 1989, 53-55. 